\title{
Os funerais de "anjinho" na literatura de viagem
}

Luiz Lima Vailati*

Doutorando/USP

RESUMO

Este artigo procura mostrar como a literatura de viagem pode ser de grande préstimo para o estudo dos temas da morte e da infância no Brasil dos oitocentos, uma vez que eles descrevem funerais de "anjinho". A partir de exemplos de como esses viajantes interpretaram essas práticas, o artigo procura argumentar que uma leitura crítica dessas narrativas nos permite ver além dos preconceitos desses estrangeiros, em especial a idéia de que aqui a criança era objeto de um completo descaso.

Palavras-chave: morte (rituais); infância, viajantes.

\section{ABSTRACT}

This article intends to show that travel writings are very important for the study of childhood and death in Brazil during the nineteenth century, because they describes "little angels"'funerals. A critical reading of theses accounts allows us to see beyond travellers'misconceptions, specially concerning the idea that children were considered unimportant in Brazilian society.

Keywords: death (rituals); childhood; travellers.

É do conhecimento de todos aqueles que têm se dedicado ao estudo do cotidiano no Brasil durante a Colônia e o Império a importância de uma literatura constituída de relatos e memórias de viagem. Esses escritos se tornam bastante freqüentes a partir de 1808 como resultado da franquia do País aos estrangeiros quando do estabelecimento da corte de D. João VI no Rio de Janeiro. Tais narrativas, quando submetidas a um crivo criterioso, têm se revelado fontes fundamentais para o desenvolvimento de temas como a família, as relações de gênero, a alimentação, as práticas religiosas, as formas de convívio e sociabilidade, dentre outras. Seu valor fica evidenciado quando se tem em vista a escassez documental, dificuldade com a qual se depara o investigador dos costumes no Brasil. Este é o caso da pesquisa da qual este artigo faz parte, que tem sob foco as práticas e representações da morte da criança nas cidades de São Paulo e Rio de Janeiro. A escolha deste objeto se justifica, uma vez que parece ser um ângulo singularmente privilegiado na avaliação de uma 
questão ainda não suficientemente trabalhada pela historiografia brasileira, a da sensibilidade em relação à infância ${ }^{1}$. Além disso, no caso dos comportamentos em torno da morte no Brasil, a literatura de viagem tem ainda um outro significado bastante especial. A origem do interesse que até hoje esse tema suscita coincide com a produção dessas narrativas sobre o Brasil. Essa constatação nos chama a atenção para o grau em que todos aqueles que de um modo ou de outro pensaram nesse fenômeno são tributários desses primeiros escritos. Mais precisamente, essa literatura serviu de referência àqueles que escreveram e avaliaram os costumes funerários no Brasil, fossem eles os médicos e políticos modernizadores do Segundo Império e da República Velha, passando por nossos primeiros "etnólogos" até a historiografia atual.

O caráter de espetáculo e a ampla mobilização social e material dos ritos fúnebres no Brasil, característica compartilhada com as demais manifestações de religiosidade, parecia neles atingir uma de suas formas mais radicais. Disso resultou a atenção que esses cientistas, missionários, comerciantes, agentes governamentais, militares ou meros aventureiros voltaram ao cerimonial mortuário, fazendo com que este fosse um dos aspectos do nosso cotidiano que também merecesse registro. É certo que tal atração fora matizada com uma amplitude de sentimentos que variaram da indignação à admiração, ainda que esta última fosse menos freqüente, é forçoso reconhecer. De modo geral, esses senhores - e algumas poucas senhoras - viam nessas celebrações o resultado não só de uma espiritualidade primitiva, cujo dolo era atribuído sobretudo à ação da Igreja Católica no País, como também de uma certa promiscuidade daqueles costumes de origem nativa e adventícia. De qualquer maneira, no conjunto dos gestos que compunham as práticas fúnebres no Brasil dos oitocentos, uma modalidade em particular era alvo da atenção desses viajantes, posto que única: os funerais de "anjinho". Ao acentuar as características presentes nos demais cerimoniais fúnebres brasileiros, os rituais de morte infantil estavam mais do que nunca distantes dos costumes mortuários que estes haviam experimentado em seus lugares de origem. Isso tornava possível que eles se assumissem como um dos símbolos do pitoresco cultural desse "país tropical". É certo que esses relatos chamam atenção para aspectos que só a distância cultural permitia entrever, daí advindo o valor inestimável dessa documentação. Todavia, a avaliação e descrição que estes viajantes faziam desses fenômenos não deixou de ser eivada de uma série de preconceitos, cuja superação cabe a uma leitura crítica dessas fontes.

Antes de iniciar a análise, algumas considerações são úteis na desconstrução do viés com que esses viajantes avaliaram nossos costumes funerários e, por conseguinte, creio que permitirão um melhor aproveitamento dessas fontes. Em linhas gerais, dois elementos constituintes do contexto de origem desses viajantes vão estar diretamente implicados na experiência que tiveram 
dos funerais no Brasil. Um deles diz respeito à formação religiosa desses senhores, muitos deles protestantes, fossem eles anglicanos (no caso dos ingleses), luteranos (na maioria alemães), e calvinistas (norte-americanos, principalmente presbiterianos e metodistas). É importante assinalar nessas Igrejas reformadas o caráter mais individualista e introspectivo de experiência e um conteúdo ético de conduta mais preponderante, o que em última instância reservava à relação do indivíduo com Deus o único ponto a considerar na sua salvação após a morte. No caso dos católicos, no geral os franceses, muitos deles já participavam de um religiosidade mais racionalista, já muito diferente da que era corrente então aqui. Essa visão fez com esses estrangeiros ficassem pouco sensíveis aos significados de muitas das práticas de religiosidade popular católicas. No nosso caso, ao caráter público dos funerais, resultado dentre outras coisas, de uma concepção na qual a salvação da alma dependia também da ação da comunidade (não só a dos vivos, como também a dos mortos - parentes e santos, conforme assinalara o trabalho de Chaunu para a Europa barroca). Da mesma incompreensão sofreram, como veremos, outras manifestações presentes nos funerais que, como outras demonstrações de fé comuns no Brasil, primavam por sua exterioridade.

Somada a isso, outra particularidade que conformava o universo de representações desses viajantes era a visão que estes então tinham em torno da criança. Como conseqüência das mudanças que começam a ocorrer na Europa no final do século XIV, com o crescimento das cidades e que determinarão sérias mudanças na consciência dos homens sobre si próprios e o mundo, dáse o início de uma lenta transformação no sentimento em relação à criança ${ }^{2}$. Esses processos se aceleram a partir do século XVII, e, segundo Philippe Ariès ${ }^{3}$, o século XIX é marcado por ser o momento em que a criança passa a ser percebida como definitivamente distinta dos adultos. O resultado dessa nova percepção da infância será o desenvolvimento de novas técnicas, valores e interditos comportamentais que passaram a serem vistos como os mais adequados em relação à criança. Além disso, este vai ser um período em que a criança adquire uma importância até então inédita, assumindo-se como elemento central na célula familiar burguesa, cujo papel social era visto como cada vez maior. Este fato é, por exemplo, comprovado na produção literária francesa que, segundo o estudo de Chombart de Louwe, a partir de 1850 conhece a entrada maciça da personagem da criança ${ }^{4}$. A emergência desse novo estatuto da infância não teria deixado de ter sérias implicações na forma como esses europeu passaram a encarar a morte infantil, de formal tal que levou um historiador da morte a afirmar que no século XIX ela seria sentida como "a mais

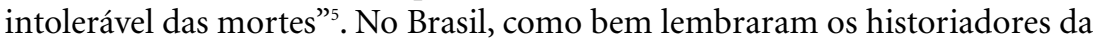
infância, não tiveram lugar essas condições que permitiram o desenvolvimento desse sentimento peculiar de infância, como uma urbanização dos costu- 
mes e a constituição de uma vida privada nos moldes europeus ${ }^{6}$. Considerando isso já é possível de algum modo antever a reação desses viajantes diante dos comportamentos comuns aos funerais de criança na Corte. Toda peculiaridade se arriscava a violentar severamente os novos preceitos desses homens sobre a criança e ao que a ela era devido.

\section{IMPRESSÕES GERAIS}

Vejamos primeiro quais eram as impressões mais imediatas e marcantes que exerciam os ritos funerários infantis sobre esses autores. Quando acontecia a esses viajantes presenciarem tanto funerais de adultos como os de crianças, a surpresa que em geral esse espetáculo dava lugar era várias vezes ampliada pelo contraste desconcertante que isso propiciava. Com efeito, sobre os gestos que compunham as práticas fúnebres infantis tomadas em conjunto, a primeira coisa que ocorria a eles era que a morte da criança comportava um comportamento que lhe era próprio e que a distinguia em definitivo dos cerimoniais fúnebres de adultos. Não é outro o motivo que levou o pastor metodista Daniel Kidder, em meados da década de 1830, a ser enfático na afirmação de que, ao se fazer um paralelo entre os funerais de adultos e os de crianças, "o contraste é maior do que se possa imaginar"

Primeiramente, o que para esses estrangeiros parecia marcar essa distinção era o aspecto comemorativo que tinham os enterros de criança. Esta característica fez com que estes fossem percebidos por parte dos viajantes como festas apenas e não um cerimonial cujo ritual específico contava com elementos comuns a outras manifestações festivas. Em linhas gerais, essa experiência se lhes afigurava sob o seguinte esquema: morte de adulto/cerimonial circunspecto/tristeza X morte de criança/cerimonial festivo/júbilo. Como Kidder, essa impressão é recorrente em inúmeros outros viajantes. O inglês John Candler, que passou por aqui em 1852, escreveu que esses cerimoniais muito se pareciam com festivais, assinalando neles a ausência do luto, os toques de sinos feitos singularmente - "as if for joy", conforme imaginou - e amigos distribuindo congratulações aos parentes do defunto ${ }^{8}$. Ao pastor metodista John Luccock teria chamado a atenção o fato de se manisfestar "entre os parentes mais distantes, maior complacência que pesar e, mesmo na mãe, nenhuma dor profunda, nada que ao menos pudesse distinguir dos outros acompanhantes". A mesma observação é ponderada por Ferdinand Denis, que esteve no Rio de Janeiro durante a década de $1830^{10}$. De fato, mais do que qualquer outra coisa, são os "yeux secs" dos participantes desses funerais que causam perplexidade ao francês M. J. Arago, em $1839^{11}$. Somando-se à visão que enfocava esses costumes fúnebres como produto de uma mistura de supersti- 
ções de origens as mais diversas, a morte da criança, para alguns deles, dizia mais: ela testemunhava, de maneira inequívoca, o fraco sentimento familiar, em particular o de maternidade, de que sofria a sociedade brasileira. Não é por outras razões que se escandalizara J. Luccock, segundo o qual, em virtude dessa situação, o futuro do Império estaria para sempre comprometido ${ }^{12}$.

Eles, certamente, não foram obtusos por completo ao conceber como tais os funerais infantis. O erro está em considerar as manifestações constituintes dos enterros dos "inocentes" como derivadas de um certo desprezo pela criança que tornaria possível a comemoração de seu falecimento. Nos funerais infantis, a despeito do que acreditaram esses estrangeiros, havia bastante lugar para a expressão inequívoca de afeto e consideração para com a criança morta. E disso nos dão conta as próprias narrativas de viagem. Na segunda década do XIX, Maria Grahan, ao falar da Casa dos Expostos do Rio de Janeiro, instituição de acolhimento de crianças abandonadas, acrescenta que ali apareciam também "crianças mortas, a fim de que sejam decentemente enterradas". Sobre bebês mortos que era comum encontrarem-se nas rodas (dispositivos onde eram depositadas as crianças para que a casa os recebesse) igualmente nos informa Daniel Kidder ${ }^{13}$. De fato, esta prática não só patenteia a existência de uma preocupação com o que seria feito desses "inocentes", como também sobre a extensão social deste costume, que atinge, por sinal, até aqueles que, devido à suas carências materiais, não deixa de ser surpreendente a demonstração de tal desassossego. Confirmando também essa disposição entre os menos abastados temos o caso das escravas libertas, que como observara Daniel Kidder, comumente empregavam parte considerável de seu parco pecúlio na tentativa de garantir um enterro para seus pequeninos que estivesse em conformidade com o que se esperava desse tipo de evento $^{14}$. Os cuidados com os rituais fúnebres infantis eram, a partir do que essas práticas nos permitem entrever, um dever ao qual ninguém parece se furtar. Não foi Arago (um dos denunciantes da alegria gerada pela morte da criança entre os brasileiros) ele próprio surpreendido pelo fato de estarem damas afoita e repetidamente a beijar o rosto da criança cujo funeral ele presencia$\mathrm{ra}^{15}$ ? Para além de qualquer menosprezo do qual a criança podia ser vítima nesta sociedade, o que está na base deste comportamento é uma determinada concepção de morte e de infância que imprimia uma certa positividade a um evento certamente traumático.

Não é surpreendente que entre os mais bem situados financeiramente - ou que assim quisessem ser tomados por - esse desvelo tivesse se traduzido em grande pompa. De fato, a outra característica desses enterros de "anjo" que marcava a experiência desses estrangeiros era o investimento exagerado. Tal era o dispêndio (material e simbólico) invertido nessas cerimônias, que não poucas vezes chocavam aqueles que estiveram de passagem por aqui 
no correr do século dezenove. "Procissão triunfal", é como define Kidder sobre um dos funerais que assiste ${ }^{16}$. O marinheiro americano Charles Samuel Stuart é mais enfático: do enterro que testemunha, recorda não só como "splendid" mas também, "the only spectacle of interest I met" ${ }^{17}$. De tal forma esse investimento hiperbólico alimentou a imaginação destes europeus que alguns como Dabadie (cujos exageros preconceituosos lhe granjearam a antipatia de G. Freyre), afirmavam ser comum, no Brasil, pessoas se arruinarem para enterrar seus familiares com uma "pompa real". Ele acrescentava que, muitas vezes pelo luxo empregado se tinha em conta que um certo funeral era de um príncipe, ao menos de um senador, quando na verdade o defunto se tratava de uma criança de "origem modesta"18.

Sem dúvida, a liberalidade de que a morte da criança era objeto perante as autoridades episcopais deve ter fomentado a utilização dos funerais infantis como suporte privilegiado de uma manifestação ostentatória tão comum entre as elites tradicionais no Brasil. Como já foi há muito apontado por estudiosos como Gilberto Freyre e Sérgio Buarque de Holanda, as distinções sociais no Brasil, na ausência de signos estáveis e perenes — tais como gozavam a nobreza européia - costumaram-se assentar no amplo uso de recursos materiais de natureza supérflua, sendo as festas e cerimônias religiosas as ocasiões propícias a dar lugar a essas expressões tão adequadas a uma sensibilidade barroca ${ }^{19}$. Nos casos dos funerais, a Igreja tridentina tentará a todo custo se opor a estas tendências, atitude revelada numa legislação fúnebre inclinada a limitar tais exageros. Quando se observa que o cerimonial mortuário infantil era deixado de lado por parte das autoridades religiosas, às quais parecia pouco importar a forma como era realizado, não é surpreendente que as elites coloniais se aproveitassem dessa ocasião para, mais do que em qualquer outra, colocar o espetáculo a serviço da manutenção de representações cuja função era dar conta da reprodução da hierarquia social. Resta lembrar, não obstante, que o caráter espetacular dos funerais infantis dizia respeito também a uma certa concepção não só do que era a criança como também sobre a natureza da fé, que deveria se exprimir o mais visivelmente possível. Temos aqui, por conseguinte, um bom exemplo de como a religião dos viajantes, principalmente os de origem protestante, de caráter mais introspectivo, os impedia de ter uma compreensão mais ampla do fenômeno funerário no Brasil.

\section{O “ANJINHO”}

Afora essas impressões mais gerais, o que os viajantes nos informam, de fato, dos funerais infantis? Apesar do grande número de viajantes que se interessaram em registrar suas experiências dos enterros de "anjinho" no Brasil, 
não temos nenhum que tenha feito uma descrição completa com todos os eventos que se seguiam à morte de uma criança. É possível afirmar que, de modo geral, estes relatos se concentram em dois momentos particulares do cerimonial fúnebre de criança: um deles, que diz respeito à forma como se apresentava o cadáver à visitação, nos informando sobre como o corpo era preparado e sobre o aparato material que o acompanhava; o outro é a procissão fúnebre, sendo que vez por outra fazem descrições sobre os lugares e formas de enterramento e alguns cuidados pós-sepultamento.

Sobre o "anjinho", os visitantes estrangeiros se mostraram favoravelmente surpresos pelo esmero em que esses pequenos defuntos eram arrumados e expostos. "Prazerosamente", "ricamente" são os termos por meio dos quais homens como John Lucccock, já no começo do período estudado, e mais tarde Daniel Kidder ${ }^{20}$, lançam mão para descrever a maneira pela qual eram preparadas as crianças. Nesse fato se encontra, dentro do conjunto das práticas fúnebres, a primeira manifestação de que às crianças mortas não se votava qualquer tipo de menosprezo. Diferentemente do que hoje isso nos possa parecer, essa dimensão do gestual funerário está bem longe de ter uma importância secundária, restrita ao plano estético, conforme parece ter sido interpretada por esses estrangeiros. Tendo origem em tempos nos quais a crença na separação entre corpo e alma após a morte não era algo bem definido, a idéia de que a forma como se era enterrado e também como se entraria no além resistiu por muito tempo aqui. Assumindo uma dimensão de insondável importância, devia-se cuidar do aspecto pelo qual o corpo se ia apresentar no reino dos mortos, e disso dependia mesmo a direção que a alma irremediavelmente tomaria na geografia do outro mundo. De tal modo a escolha da última roupa interferia nos destinos da alma, que todo aquele que testava procurava informar em detalhe como queria estar vestido nessa ocasião ${ }^{21}$.

Residindo no Brasil em meados da década de 1840, Thomas Ewbank mostrou-se particularmente interessado por esse aspecto do cerimonial fúnebre no Brasil. No caso das crianças, ele nos informa que em alguns casos as crianças eram vestidas como santos:

As crianças com menos de 10 e 11 anos são vestidas de frades, freiras, santos e anjos. Quando se veste de São João o cadáver de um menino, coloca-se uma pena em uma das mãos e um livro na outra. Quando é enterrado como São José, um bordão coroado de flores toma o lugar da pena, pois José tinha um cajado que florescia com o de Araão. A criança que tem o mesmo nome que São Francisco ou Santo Antônio usa geralmente como mortalha um hábito de monge e capuz. Para os maiores, São Miguel Arcanjo é o modelo. Veste-se então o pequeno cadáver com uma túnica, uma saia curta presa por um cinto, um capacete dourado (de papelão dourado) e apertadas botas vermelhas, com a mão direita 
apoiada sobre o punho de uma espada. As meninas representam "madonas" e outras figuras populares ${ }^{22}$.

A preferência pelas vestes de santos já à primeira vista não nos causa estranheza, visto serem deste tipo as mortalhas que eram de costume utilizadas como derradeira roupa. Isso estava de acordo com uma crença na qual o falecido, vestido desse modo, seria favorecido pela intervenção do santo - que o receberia e o guiaria em direção ao Céu — de cujo hábito escolhera por mortalha. Era muito comum, conforme acrescentara Ewbank, que se vestissem as crianças com o hábito do santo de seu nome. Assim, seu protetor em vida não lhe faltaria na morte. Desta forma, era natural que se escolhessem santos de sua predileção ou patronos de sua irmandade. Isso nos permite acreditar que, cobrindo a criança com as roupas deste ou daquele santo, os pais garantiam que seu rebento não ficaria desamparado no outro mundo, estando guardado sob os cuidados dessas entidades. Como certamente não o fora enquanto era viva, não era indiferente aos pais o que poderia acontecer à criança quando morta.

Além disso, é possível avançar a afirmação de que essa prática estava relacionada com razões que são ainda mais específicas de uma certa sensibilidade para com a criança. Ela diz respeito a uma crença no papel de intermediária que a criança morta ocupa entre os vivos e as autoridades celestes. Essa função se assentava no estado de pureza com a qual ela era caracterizada e que já garantia prerrogativas especiais à criança quando viva. Encontrandose morta, estava em contato mais direto com os santos e, por conseguinte, esse poder de intermediação entre os homens e as entidades celestiais era potencializado. Mais do que nunca, escolher a mortalha de um santo em particular significava a possibilidade de melhor explorar esse poder tendo em vista um objetivo mais preciso, uma vez que, no universo da religiosidade popular, cada santo é "especialista" em determinado tipo de providências.

Levar em conta essa concepção nos leva, portanto, a perguntar pelas razões que faziam com que determinadas mortalhas de santo fossem escolhidas $^{23}$. João José Reis, em seu trabalho sobre a Bahia, mostrou brilhantemente como algumas das vestes preferencialmente utilizadas no caso de crianças estão relacionadas à questão da procriação ${ }^{24}$. Ora, o vínculo entre as "madonas" apontadas por Ewbank e o tema é evidente (temos condições de saber que eram elas, em sua maioria Nossas Senhoras da Conceição e Nossas Senhoras das Dores). No cerimonial fúnebre infantil, para além dos cuidados tendo em vista a salvação do morto e a proteção dos vivos, uma outra preocupação a elas se soma: a manutenção da linhagem que é comprometida com a perda filial. E é isso que permite entender a preferência dada a determinadas mortalhas para a criança morta. Ora, com a morte de um filho, em que outro mo- 
mento seria mais premente o desejo de se ter outro, e que outra forma seria mais eficiente de assegurar a sua concretização do que enviar o "inocente" ao encontro desses santos que, dada a condição tão especial do mensageiro, não deixariam de receber e atender a esse pedido?

Vimos que Ewbank descreve ainda uma outra mortalha, cujo uso é bastante significativo: a veste de anjo (no caso dele, a de São Miguel). Na morte, fica ainda mais evidente a associação feita entre a criança e a figura do anjo, paralelo já constatável no uso do termo "anjinho" para designar a criança morta. A relação entre eles é tão forte, que a morte não era a única circunstância em que a criança tinha a oportunidade de se vestir como tal. Sabemos disso por intemédio das descrições que viajantes como Debret e Ernst Ebel na década de 1820, Ferdinand Denis em 1838, Daniel Kidder em 1840, T. Ewbank em 1845, Oscar Canstat em 1868, deixaram de outros acontecimentos comuns aqui no Brasil, em especial das procissões em que crianças (no geral menores de sete anos, como salientam estes relatos) saíam representando anjos, cujas descrições são bastante semelhantes às destas mortalhas — asas artificiais; perucas; profusão de pedras, etc ${ }^{25}$. Ainda nesses casos, todavia, há uma forte proximidade entre as representações dos anjos e a temática da morte. A procissão em que por excelência os anjos desfilam é precisamente a do Corpo de Cristo, que não é outra coisa senão um cortejo fúnebre, o maior deles. Além de reafirmar uma série de valores agregados à criança morta, como seu estado de pureza que toma corpo na figura do anjo, o uso das vestes angelicais acentua igualmente outras características comuns às outras dimensões dos enterros dos inocentes, como é o caso da ostentação material, tem nelas um suporte especial. Esse tipo de mortalha, composto de plumas e sedas e muitas jóias, chamou a atenção de estrangeiros como Stewart em 1829, Siedler em 1835 e Candler na década de $1850^{26}$.

Viajantes como Kidder e Debret (este último deixando ilustrações de enterros de crianças escravas), registraram o uso do pano branco como mortalha $^{27}$. Bem mais simples que aquelas descritas por Ewbank, essas mortalhas eram mais comuns entre as camadas mais humildes, e principalmente entre os escravos recém-chegados da África. Os costumes funerários transplantados deste continente devem ter contribuído consideravelmente para isso. Muitos autores, como Jean Chevalier, apontam para o fato de a cor branca ser, entre os africanos, a cor por excelência da morte e dos mortos ${ }^{28}$. A esse significado deve-se acrescentar aquele que a liturgia cristã atribuía ao branco, a cor da alegria e, antes de tudo, da inocência e da pureza virginal. De fato, como veremos adiante, o branco aparece em outros elementos dos funerais de crianças (africanas ou não) descritos pelos viajantes ${ }^{29}$. A morte da criança, na liberalidade resultante do pouco interesse que ela desperta por parte da Igreja no Brasil, aparece também como suporte privilegiado de práticas culturais com- 
plexas e variadas tão marcantes na religiosidade popular do País, dando exemplo de como a similaridade simbólica entre esses corpos de crença deu condições para a existência de tais manifestações miscigenadas.

Além do hábito, esses estrangeiros fizeram referência a outros cuidados na preparação do "anjinho" para o enterro, em especial a alguns aspectos característicos dos rituais fúnebres infantis que já são observáveis nesse primeiro momento. Um deles é o de arrumar o cadáver de forma a lhe restituir o aspecto que tinha quando vivo, por intermédio da maquiagem. O francês Gendrin lembra do amplo uso desse material em cadáveres que, dentre outras coisas, eram apresentados com lábios e faces avermelhadas e cabelos empoados $^{30}$. Como em outros procedimentos, isso também se apresentava na criança, de forma hiperbólica. Arago lembra da pequena menina morta cujas faces lhe foram pintadas em abundância de um rosa brilhante, resultando numa aparência que lhe fez lembrar "les acteurs au théâtre" ${ }^{31}$. Conforme verificado pelo mesmo viajante, não podiam faltar outros adereços, que iam das fitas coloridas e flores artificiais às pedras preciosas, fato confirmado também por Enest Ebel, Ferdinand Denis, Daniel Kidder, Carl Siedler e Wetherell que na Corte estiveram por um período que cobre três décadas ${ }^{32}$.

Por sinal, os dois autores que perfazem as pontas desses trinta anos (Ebel, e Wetherell, portanto), repararam, dentre esses adornos, numa peça fundamental: a coroa dourada sobre a cabeça ${ }^{33}$. Esse elemento devia estar intimamente associado à idéia de castidade, ao menos entre os leigos. No Brasil, sabemos do uso, condenado pela Igreja, de pôr coroas nas jovens solteiras mortas. Nos escritos judaicos cristãos, o uso da coroa possui significados os mais variados, mas todos sugestivos. Um deles é que a coroa representa a imortalidade dos mártires. Com efeito, é bastante recorrente a associação feita entre a criança morta e o mártir, com particular referência àqueles bebês mortos por ordem de Herodes, os "Santos Inocentes". O outro significado está relacionado ao batismo, e, para alguns autores, a imagem da coroa está "indissoluvelmente ligada à do paraíso" ${ }^{34}$. Mais uma vez, temos a presença de um elemento a assinalar a crença na certeza da salvação infantil. A esses significados pode-se acrescentar um outro, talvez mais relacionado a uma concepção leiga: a idéia de castidade.

Um outro artefato bastante freqüente nos funerais dos “inocentes” de que os viajantes fizeram referência é o pano branco bordado ou a toalha de renda. Este artigo era interposto entre o corpo e o suporte onde ele era depositado, fosse ele o caixão ou qualquer outro instrumento utilizado com essa finalidade. Como é o caso da mortalha branca, o uso do pano de renda parece ter sido alvo de uma certa predileção pela comunidade africana, e estendia a outros elementos do funeral infantil a eficácia simbólica do branco. Além das ilustrações de Debret que nos dão notícia deste costume, temos o depoi- 
mento de Kidder e de Ferdinand Denis, que tiveram a oportunidade excepcional de assistir a um funeral infantil africano, visto que, na propriedade rural do imperador em Engenho Velho religiões adventícias eram toleradas, conforme atestam esses autores. Essas descrições assinalam o uso, além dos arranjos com flores que cercam o morto - chamando atenção de Kidder um ramalhete atado a uma das mãos do pequeno cadáver - estava presente a toalha de renda branca ${ }^{35}$. De qualquer maneira, o que fica demonstrado por esse costume é que, ainda que os africanos no geral tivessem um uso mais extensivo do branco nos rituais de morte - visto que os adultos são também amortalhados de branco -, a relação entre a criança e a pureza que o branco encerra é reforçada.

O caixão foi outro elemento que chamou a atenção dos viajantes. Da sua leitura fica claro que para o início do período estudado o seu uso não tinha ainda papel fundamental que mais tarde conhece dentro do aparato material que compõe a ritualística fúnebre infantil. Segundo Debret, o esquife servia principalmente de suporte à exposição e transporte do cadáver, e uma vez que o corpo não era enterrado dentro dele, um mesmo esquife era utilizado em diversos funerais ${ }^{36}$. É o artista francês quem, nesse aspecto, traça o quadro mais detalhado: para as crianças mortas de família medianamente abastada era comum se utilizar para o transporte do corpo um caixão sem tampa tal como acontece com os adultos de mesma condição - com forro de tafetá branco ou cor-de-rosa e galonado em prata. Para os que possuíam definitivamente maiores recursos, havia o caixão fechado, cuja tampa se abria em duas folhas, uma para cada lado, também este coberto de seda cor-de-rosa, forrado de branco com galões de ouro ou prata. Em 1824, uma descrição de Ernest Ebel confirma o uso de um mesmo tipo de féretro no enterro de um recém-nascido ${ }^{37}$. Entre as crianças, as diferenças de idade davam margem para variações: nos caixões de crianças de menos de oito anos, conforme salienta Debret, o rosa podia dar lugar ao azul-celeste (cor também comum entre as moças). Como de costume, o uso dessas cores e da prata contrastava com preto e o carmezim para repectivamente os caixões de homens e mulheres, ambos galonados de ouro. Ewbank, em 1845, confirmou essa tendência, dizendo simplesmente que os caixões vivamente coloridos (vermelhos, escarlates e azuis) eram próprios de defuntos jovens e crianças, utilizando-se os adultos, do preto, fato confirmado cinqüenta anos mais tarde pela norte-americana Marguerite Dickins ${ }^{38}$.

Como se vê, é nas descrições dos caixões que vemos pela primeira vez a referência ao vermelho (ou de seu equivalente, o rosa), elemento de imensa importância nos funerais de "anjinho". O carmim, que outras fontes nos informam ser uma das cores preferidas para mortalhas das crianças, cor dominante em outros aspectos do aparato funerário, tem na liturgia católica um 
uso que nos é extremamente significativo. O vermelho é, por excelência, a cor dos mártires e, no caso do vermelho-claro, dos anjos ${ }^{39}$. Um viajante mesmo teve oportunidade de constatar esta relação no Brasil. Como observara Thomas Lindey em 1805, essa não só era a cor do hábito dos sacerdotes nas celebrações para as Almas dos Mortos, mas, para o que nos interessa mais particularmente, essa era a cor utilizada também para as celebrações feitas no dia dos Santos Inocentes, denominação dada aos mártires bebês mortos por ordem de Herodes ${ }^{40}$.

Nesse âmbito, segundo as referências que temos para os escravos, imperava, no geral, a mais completa simplicidade. Gendrin nos informa sobre o costume de se enterrar os escravos nas redes que serviram de leito quando eram vivos, sem qualquer tipo de lençol ${ }^{41}$. Debret, por sua vez, nos fala do uso, para crianças escravas, de um pequeno caixão forrado de ramalhetes de flores artificiais, alugado dos "armadores" e, para aqueles que não podiam arcar com o aluguel de um simples caixão, lançava-se mão de um tabuleiro recoberto por uma toalha de renda. O uso de uma bandeja de madeira nos enterros de crianças africanas foi igualmente observado por Kidder ${ }^{42}$.

Nesse aspecto, os viajantes nos dão notícia de uma transformação em termos de um maior dispêndio no que respeita à cultura material mortuária, que é perceptível sobretudo pela introdução de um costume novo por parte da parcela melhor aquinhoada da população: o de se enterrar os defuntos junto com o caixão. Como já foi dito, no Brasil, as referências a esse novo procedimento estão relacionadas às narrativas que os viajantes estrangeiros faziam dos acontecimentos que tinham lugar nas celebrações do Dia de Todos os Santos. Neste dia, as catacumbas das igrejas expunham à visita os caixões e urnas com as quais mortos ali eram enterrados. Esse fato por si só já é indicativo de uma tendência no sentido de um incremento material no interior da ritualística fúnebre, visto que esse costume implicava a aquisição de um produto que, como vimos, era antes alugado.

Além disso, as urnas funerárias, aquelas mesmas que durante muito tempo havia sido costume expor à visitação pública no Dia de Todos os Santos, sofreram importantes transformações. A violência desse movimento foi tamanha que foi percebida pelos próprios viajantes em questão de décadas. Disso nos presta valioso testemunho Debret, quando observou que, a partir de 1816 , já se podia ver obras-primas de marcenaria, que teriam se transformado, a partir do final de 1820, em "monstruosidades", resultado de artistas entregues à "fuga de sua imaginação" e à extravagância dos parentes, e que se traduziam em prateados e dourados excessivos e através, segundo ele, de grosseiras imitações de mármore ${ }^{43}$. Situação já plenamente configurada quando seu conterrâneo Gendrin lembrava, quarenta anos depois, dos caixões forrados de veludo galonado em ouro ou prata, artefato que causava enorme se- 
dução na população em geral, demonstrada pelas multidões que corriam a visitar as catacumbas quando da exposição dessas urnas ${ }^{44}$. Essas mudanças chegam a ponto de Daniel Kidder falar desses féretros adornados com brocados de ouro que muitos eram "grandes como mausoléus" 4 .

Esse movimento no sentido de um enriquecimento material do aparato fúnebre ao longo do século XIX, observável pelas informações que nos oferecem as narrativas de viagem, está evidentemente ligado ao crescimento e enriquecimento que as cidades brasileiras conheceram durante esse período ${ }^{46}$. Este é o caso principalmente do Rio de Janeiro, cidade da qual a quase totalidade das narrativas aqui apresentadas dizem respeito. $\mathrm{O}$ testemunho fúnebre lança luz sobre a relação entre o desenvolvimento dessas cidades e da sua vida urbana e a incorporação de novos hábitos. Já nesse âmbito fica evidenciado que uma nova disposição de consumo, perceptível pela riqueza dos artefatos fúnebres, não significou uma simples adoção de práticas fúnebres correntes na Europa. Tendo em vista que, para que isso ocorresse, seria necessário um enxerto de sensibilidades e concepções de morte - no nosso caso, infantil a tal ponto distinta, que dela resultou o completo estranhamento e incompreensão com que reagiram às práticas fúnebres infantis nossos observadores estrangeiros.

\section{O CORTEJO FÚNEBRE}

Como foi dito, outro momento dos funerais infantis freqüentemente registrados nos relatos de viagem é o cortejo fúnebre. É a ocasião em que o corpo deixa o local onde era visitado (geralmente a residência) e se dirige à igreja, na qual, até a metade do século XIX, era enterrado. De todas as etapas que compunham o cerimonial fúnebre infantil, esta foi a que mais chamou a atenção dos viajantes, resultando na maior parte dos registros que eles fizeram deste assunto. Não era para menos. Era a procissão fúnebre o ponto alto da participação coletiva que compunha os rituais de morte tradicionais, ocasião em que o caráter público dos funerais se manifestava com maior intensidade - a cidade toda era chamada a participar deles. A morte infantil, com a permissividade ritual que a caracterizava, não deixou de potencializar em alto grau essa caraterística. Por esse motivo, esse conjunto constituído pela procissão e transporte do cadáver revela a forte tendência que a morte da criança tinha, ora de exacerbamento das atitudes que a morte como um todo engendrava, ora de inversão destas mesmas - no sentido de deslocar a gravidade comum aos funerais dos adultos para um outro tipo de postura. Vejamos.

Durante grande parte do século XIX brasileiro, rezava o costume de realizar o translado do corpo à igreja para ali ser enterrado (hábito que, por dois 
séculos, será debaldadamente combatido pelas autoridades eclesiásticas e médicas, até que fosse definitivamente abandonado) à noite ${ }^{47}$. Ora, segundo experiência também compartilhada por outros viajantes, o francês Arago, vagando pelas ruas da Corte, foi surpreendido, ao dobrar uma esquina, com um cortejo fúnebre "en plein jour": tratava-se de um pequeno defunto com destino ao cemitério ${ }^{48}$. Com efeito, esse diferença não passou despercebida a Kidder que, ao enumerá-las, lhe ocorreu mencionar, em primeiro lugar, a questão do período do dia em que essas cerimônias aconteciam. Estamos novamente diante de uma prática que relaciona a morte da criança a um acontecimento cujo sucesso já se conhece de antemão. As cerimônias de um adulto eram noturnas, com tudo aquilo que a noite encerra de mistérios e perigos, em bastante conformidade com o que se acreditava serem os primeiros momentos que presidiam a passagem para o além. O dia, por sua vez, é o lugar do cotidiano, daquilo que é familiar. Se o defunto adulto realizava sua última viagem nas trevas, como referência ao seu decisivo e desafiador trajeto para o outro mundo, onde até os mais pios poderiam se perder, para a criança morta esse transportar-se não comportava risco ou surpresa. As procissões diurnas eram índice de que se dava por garantido sua salvação.

Mas a luminosidade que o dia proporciona parece ter também uma outra função aqui. Uma delas é dar condições para que o cadáver seja visto por maior número de gente possível. Os tanato-historiadores estão de acordo com o fato de que, nos funerais ocidentais barrocos, o morto presidia o espetáculo (eles eram, em parte, isso), visto que esse acontecimento era por ele planejado em testamento nos seus mínimos detalhes. Nos enterros de criança o morto era, ele próprio, o espetáculo. Aos participantes, desincumbidos de prestar auxílio tanto ao defunto, em momento em que se faz necessário reunir forças para o bom encaminhamento do translado espiritual, como aos familiares, estes em processo de reordenamento tendo em vista a superação do vácuo social que a morte de um adulto geralmente produz, cabe uma única atitude, a de louvar o pequeno falecido. Sendo assim, é a ele que todos os olhares se dirigem, o que explica em grande parte o esmero com que é preparado. É em virtude disso que a principal característica do funeral infantil nessa fase do cerimonial era a superexposição do morto, elemento que também chamou a atenção dos viajantes. De fato, a primeira coisa de que recorda acerca dos funerais infantis o marinheiro norte-americano Charles Stewart, que deles participou na década de 1820, é que os corpos das crianças "are exposed in procession through the streets" ${ }^{49}$.

Tal era o esforço para conseguir o máximo nesse sentido, que em 1845 Thomas Ewbank fora informado por brasileiros que vinte e cinco anos antes era muito comum a criança morta seguir o cortejo de pé (do estranhamento com que esse hábito se apresenta a nós, hoje, é possível vislumbrar o teor das 
transformações que tiveram lugar nas práticas e representações da morte da criança ao longo desses dois séculos). Segundo ele, para que isso fosse possível, a criança tinha os tornozelos, joelhos, braços e pescoço amarrados com fitas a um suporte de madeira em forma de cruz, fixado numa plataforma. Devidamente maquiada, em roupa de gala, sapatos de seda, uma profusão de pedras preciosas, portando numa mão uma palma, e a outra apoiada com naturalidade sobre um arrimo vertical: tudo isso resultava num efeito conjunto que tornava difícil acreditar que ali se tratasse de um cadáver, não fosse pelos olhos cerrados. Segundo esses informantes, tal prática teria sido abandonada na Corte, mas era ainda muito comum no interior ${ }^{50}$.

De todo modo, para grande parte do período enfocado, são nulas as referências a esta prática, o que aponta para a sua inexistência, principalmente nas grandes cidades. É apropriado pensar que o caráter "pitoresco" com que esse costume por certo assumiria aos olhos dos viajantes estrangeiros teria feito com que, caso fossem efetivamente presenciados, resultassem em registro. Entretanto, ainda que não tenha presenciado essa prática nos funerais dos quais participou, Luccock nota que nestes a criança era colocada num estrado de forma a também estar inteiramente à vista ${ }^{51}$. Como se vê, a disposição horizontal com a qual se tornaria regra dispor o cadáver não implicou necessariamente que a exibição exarcebada deste deixasse de ser um traço marcante dos funerais infantis. Por um bom tempo ainda permaneceria válida, por conseguinte, a constatação de que, se era comum no conjunto dos gestos que acompanhavam o cerimonial fúnebre que o defunto, como que de fato presidindo a festa, ficasse devidamente à vista de todos os que tomavam parte nesse acontecimento - considerando o uso de caixões abertos durante o cortejo -, para a criança essa tendência era bem mais acentuada.

De resto, o cortejo, na forma como era organizado, parece, à primeira vista, que em pouco ou nada se distinguia dos funerais de adulto. Como nestes últimos, ele era realizado a pé. Com efeito, segundo Ernest Ebel, que escreve nas primeiras décadas do século, as procissões fúnebres de criança, tal como as demais nesse período, eram formadas por fileiras de homens que seguiam andando ${ }^{52}$. O mesmo é dito por James Wetherell em 1856, que lembrava que quinze anos atrás, antes que fossem proibidos os enterros dentro das igrejas, a procissão que ia a ela era feita a pé, formada por uma longa fila de parentes e conhecidos, encabeçada pelos padres que carregavam velas cobertas por lanternas de papel $^{53}$.

Uma identidade entre os dois cerimoniais se estende à questão relativa à origem das pessoas que acompanham o cortejo, nas suas relações com o defunto. Nos cortejos de "anjinho" mulheres e parentes próximos do falecido eram proibidos de participar. É o que alguns viajantes - John Candler em 1852, Christopher Andrews em 1887- recordam acerca dos enterros no Brasil ${ }^{54}$ - 
. Estando de acordo com essa observação, nas descrições que estes deixaram dessas cerimônias não há qualquer alusão à presença dos pais ou de mulheres. Não se pode deixar de assinalar a considerável participação de estranhos, outro traço que compôs o caráter público dessas manifestações. É evidente que se nesse ponto os enterros de crianças eram diferentes dos demais, isso se dava tão-somente porque, como em tantos outros aspectos, esta característica se apresentava de forma mais radical. Os viajantes não só se vêem eles próprios participando de procissões fúnebres de estranhos, como ainda o fazem sem que houvesse outra escolha - em todos esses casos se tratava de enterro de "anjinho". Já se mencionou uma ocasião em que, vagando pelas ruas do Rio de Janeiro, Luccock foi convidado a participar de um cortejo fúnebre que vinha a ser de uma criança. Este evento aconteceu no início do século, tendo Ernest Ebel experiência semelhante na década de $1820^{55}$. Vinte anos mais tarde, o mesmo teria ocorrido com o francês M. J. Arago, interpelado na rua por um estranho que lhe pedira "se podia lhe fazer a gentileza de acompanhar um pequeno Jesus ao céu", ao que consentiu o viajante, acompanhando com um círio aceso que para isso lhe deram, como também havia sido feito com $\mathrm{Ebel}^{56}$.

Em todo caso, se nos funerais tanto de adulto como de criança o público que acompanha o cortejo é, nas suas relações com o cadáver, da mesma natureza (familiares, confrades, amigos, conhecidos e desconhecidos) conforme nos informam os testemunhos, isso nem sempre pode ser dito no que respeita ao comportamento por eles adotado. Chamou a atenção a Arago um outro costume, deveras destoante dos funerais de adulto e que, como tantos outros também fizeram, ele interpretou como uma manifestação de felicidade pelo ocorrido: nos enterros de criança ele notou a ausência de luto entre os participantes, que se apresentavam em "vêtements mondains" ${ }^{57}$. Esse aspecto, de fato, nos faz voltar à hipótese de uma concepção de morte infantil que se expressava não pela gravidade dos gestos, mas por uma proximidade com que é cotidiano e familiar. Por tudo aquilo que até agora foi dito, é essa concepção, mais do que um certo desprezo ou desapego à criança, que parece ter sido determinante na forma como esse cerimonial se caracterizou.

O cortejo infantil prima por sua informalidade e pela presença de elementos, por assim dizer, "festivos". Voltamos aqui ao caráter de inversão com que os cerimoniais fúnebres de criança se afiguram quando tomamos por referência os comportamentos que são comuns à morte adulta. Um exemplo mais saliente deste tipo de conduta nos oferece a experiência do oficial de reserva alemão Carl Siedler, que em 1835 seguiu o funeral de "uma criança de distinta família". Ele nos conta que a comitiva que iria acompanhar o "anjo" constou da presença de uma banda militar a qual executava uma marcha fúnebre até que, a partir de um determinado momento, por ordem do vigário, passou a tocar o chamado "miudinho" — uma espécie de música dançante 
de caráter jocoso e, muitas vezes, de forte conotação sexual. Nesse caso, a canção fazia alusão "aos secretos encantos da madona" 58 . Desnecessário acrescentar que tal feito não deixou de ter causado violenta revolta ao luterano alemão, que sofrendo forte indignação, decidiu de imediato afastar-se do cortejo.

De fato, alguns aspectos do aparato material que compõem essas procissões estavam mais de acordo com uma concepção diferenciada da morte infantil. No uso das cores, por exemplo, Daniel Kidder, em 1930, nos informa sobre a existência de tocheiros vestidos de branco com rendas prateadas nesses enterros, em franco contraste com o uso do preto nos funerais de adul$\operatorname{tos}^{59}$. Novamente vemos as cores encarregadas de promover essa distinção. Sobre a decoração desses funerais temos notícia da longevidade da preferência do uso do vermelho para crianças em lugar do preto para adultos e azul para jovens, "not children", como precisou o comerciante americano Robert Minturn, que aqui esteve no final da década de $1850^{60}$. Wetherell, na mesma época, notara o uso nesses funerais de criança da combinação entre o branco e o vermelho, de cujos significados já tivemos oportunidade de falar ${ }^{61}$. Já no final do XIX, Marguerite Dickins constatou o mesmo comportamento ${ }^{62}$.

Graças a alguns viajantes, sabemos algo a respeito dos enterros de crianças negras, no que se refere à procissão fúnebre. $\mathrm{O}$ que fica evidente é que, também entre os escravos, era bastante apreciado o costume de exibir a criança morta, ainda que isso fosse feito de forma ligeiramente diferente. Debret faz alusão a dois tipos de cortejo de "anjinho" entre os escravos. Um deles, mais luxuoso, consistia em uma cadeirinha forrada de damasco. Verifica-se também nas procissões fúnebres da criança escrava o costume de superexpor o cadáver e o fato de, para os escravos, ser também importante que o pequeno defunto seja arrumado de modo a dar a impressão de que a criança vive. O outro tipo de funeral de criança escrava, relatado por Debret, é exatamente igual ao que havia assistido Daniel Kidder, fazendo parte de um daqueles cerimoniais africanos restritos à propriedade do imperador no Engenho Velho. Segundo o artista, sabemos que o cadáver era estendido sobre uma bandeja que, por sua vez, era carregada na cabeça de um escravo adulto que, sob o cântico cadenciado dos acompanhantes, de hora em hora girava nas pontas dos pés, como se dançasse. Kidder acrescenta que, seguindo o cadáver, vinha uma multidão formada por cerca de vinte mulheres (inclusive a mãe da criança) e numerosas crianças, a maioria enfeitada com tiras de panos vermelho, branco e amarelo. Não se pode deixar de observar como o cerimonial africano se afirmava na participação das mulheres, como distinto da tradição de origem portuguesa conforme era praticada aqui. São essas pessoas, das quais a mãe da falecida se sobressaía pela gesticulação exarcebada, que se encarregavam da música que, ao que parece, se tratava de um canto em língua africana (que ele inferiu ser etíope), executada num compasso e lento e bem mar- 
cado. Outra figura que tinha papel importante nesses cortejos de criança escrava era a madrinha da criança, que geralmente se punha ao lado da falecida. Essa situação permanecia sem maiores interrupções até que se chegasse na igreja. Tendo deixado ali o corpo para ser enterrado, o cortejo voltava dançando e cantando com maior ímpeto ${ }^{63}$.

Já na primeira metade do século XIX, havia entre os mais abastados o costume de levar o caixão em carros puxados por cavalos, nos quais iam também os padres, seguindo a pé o resto do cortejo, conforme nos informa o aventureiro francês J. B. Douville, que aqui esteve em $1828^{64}$. Interessa notar que seu uso não teria implicado um imediato abandono da tendência - tão cara aos enterros de crianças, como se viu - de expor os cadáveres. Nas padiolas desses carros sem cobertura, o corpo em toda a sua produção estava inteiramente à vista em seu caixão aberto ${ }^{65}$. Não obstante, essa novidade fornece elementos que permitem vislumbrar o sentido em que se desdobraram algumas mudanças às quais estiveram sujeitos os comportamentos diante da morte como um todo. Em especial, nos dá indícios sobre a transformação desta prática que, anteriormente caracterizada pela sua publicidade, se transformou numa manifestação cada vez mais restrita ao âmbito privado. Para o período estudado, essa tendência em limitar o acesso ao cadáver e às cerimônias fúnebres a um círculo mais fechado vai se manifestar parcialmente, visto que a pompa utilizada nesses funerais não faz senão aumentar. Mas essa mudança operou-se de forma incisiva: o corpo será cada vez mais resguardado da exposição pública e do contato com estranhos.

Com efeito, a leitura dos viajantes nos permite vislumbrar mudanças importantes nesse âmbito. Acompanhando o que vinha acontecendo com os funerais de adultos, temos notícia de que já nas primeiras décadas do século algumas crianças também faziam sua última viagem em carros. Não é outra coisa que Daniel Kidder presenciou, ao final da década de 1830, numa procissão fúnebre de "anjinho", em que o pequeno féretro descoberto ia num coche também aberto no colo do pároco, este devidamente paramentado. O carro mortuário já lhe causou forte sensação: "cavalos brancos, festivamente ornamentados, com níveas plumas na cabeça" ${ }^{\text {"6 }}$. Num outro funeral de criança, vinte anos depois, o inglês John Candler testemunha um mesmo tipo de cortejo, em caixão levado em carro aberto, com o resto dos participantes a pé, mas encontrou um elemento novo: a escolta de cavaleiros vestidos de vermelho, fato que, signitivamente, pareceu a ele nada menos que uma "hunting party" ${ }^{\prime \prime}$.

Com a secularização dos cemitérios em meados do XIX, o uso de carros para o transporte do cadáver se tornaria obrigatório, ainda que inicialmente ficasse praticamente restrito às pessoas de posses. Tal é o que nos informa o comerciante francês Victor-Athanase-Gendrin, que visitou o País na década 
de 1850, imediatamente após a secularização dos cemitérios no Rio de Janeiro. Ele observou também enterros de escravos, nos quais ainda se fazia uso do costume de transportá-los numa rede sustentada por um bastão horizontal, cujas pontas eram apoiadas sobre os ombros de um carregador, estes também escravos. Não obstante, em pouco tempo esse uso parece ter-se disseminado, e não só o morto, como também todo o cortejo passou a ser feito sobre rodas. Wetherell aponta que nas procissões fúnebres por ele presenciadas em 1860 , o corpo e os enlutados faziam a viagem em carruagens. O mesmo verificou o engenheiro-agrônomo membro da Comissão Imperial de Agrimensura, Oscar Canstat, em 1868, assombrado com o luxo de um carro fúnebre "fantasticamente pintado e dourado, enfeitado de penachos nos quatro cantos, ao qual estavam atrelados quatro cavalos adornados também com penachos e longas e vistosas galdrapas. Na boléia ia um negro com um tricórnio lhe cobrindo a carapinha, gravata branca, e envergando uma libré fantásti$\mathrm{ca}{ }^{68}$. Cristopher Andrews teve, já em 1887, ocasião de presenciar esses cortejos que, segundo ele, consistiam em quarenta carruagens abertas de dois cavalos, conduzidas em marcha acelerada ${ }^{69}$.

Os pequeninos defuntos começaram também, a partir de então, a fazer sua última viagem em carruagens cobertas, distanciando-se muito, desta forma, dos antigos funerais realizados a pé. A criança, antes superexposta aos olhares de todos, fazia agora a sua última viagem escondida. O contraste não pode ser maior. Deve-se, além disso, notar que este novo costume acentuava muito o distanciamento físico do cortejo em relação ao cadáver, uma vez que não se fazia mais necessário (ou possível) que até um estranho participasse do carregamento do corpo, conforme se observou ser comum nos cerimoniais infantis. Em todo caso, o uso de carruagens no caso dos funerais infantis não implicou imediatamente o fim da participação coletiva nesses acontecimentos, é o que nos informam as narrativas. Minturn, por exemplo, descreveu aquilo que ele chamou de "a very pretty custom": a presença das flores, seja na decoração do coche, oferecida pelos amigos da família do defunto criança, ou ainda no costume dos moradores das casas situadas nas ruas onde o cortejo faz seu trajeto de jogar pétalas quando o carro faz sua passagem ${ }^{70}$.

Como de costume, todavia, os funerais de criança continuam a impressionar, pelo seu aspecto alegre e ostentatório, os estrangeiros que tiveram a oportunidade de os presenciar. Wetherell, por exemplo, lembrava de carruagens e cavalos "alegremente decorados com plumas brancas e vermelhas"71. A decoração desses carros deu continuidade à preferência do uso do vermelho para crianças em lugar do preto para adultos e azul para jovens, "not children”, como precisou o comerciante americano Robert Minturn, que aqui esteve no final da década de $1850 .{ }^{72}$ Esse hábito, ao que parece, teve bastante fôlego. Já no final do século, a norte-americana Marguerite Dickins descreveu 
uma carruagem, indo a um enterro de criança, que lhe chamara a atenção. Segundo ela, o carro estava pintado de branco até nas rodas, sendo o cocheiro e as cortinas (carro fechado, portanto) paramentados de vermelho (a que ela opõe às carruagens negras dos de adultos), conjunto que ela definiu como "gorgeous"73.

Em todo caso, a exposição característica dos funerais infantis diminui ainda mais quando se toma em consideração um outro fator: o encurtamento dos percursos envolvidos. Em conjunto com outros fatores que levaram a uma certa "secularização" das práticas fúnebres, principalmente entre os setores mais abastados da população urbana, o trajeto passou cada vez mais a prescindir da passagem pela igreja. Esse fenômeno mereceria um estudo, visto que indignou mesmo europeus (que deveriam, em tese, estar mais "aclimatados" com esse processo de secularização dos costumes) como o francês Mac-Érin, segundo o qual "une telle sépulture, si elle n'était suivi de la messe du septième jour, resemblerait tout à fait un enfouisement civil" ${ }^{74}$.

Já final do século Marguerite Dickins lembra do fato de não mais se fazerem funerais a pé. Mais ainda, ela assinala uma mudança nos costumes funerários que nos é bastante significativa. Como já fora observado por outros viajantes várias décadas antes, Dickins confirma o fato de que as mulheres não costumam acompanhar os cortejos, mas acrescenta que, neste aspecto, os funerais de criança constituem uma exceção ${ }^{75}$. Excelente testemunho de que a criança foi efetivamente o alvo privilegiado de uma valorização, até então desconhecida, dos sentimentos familiares, em que a participação nos funerais, e certamente a manifestação de um pesar que não precisa mais ser escondido, deixou de ser interditada para se tornar uma expressão legítima e, antes de tudo, digna de louvor.

\section{ENTERROS E RITUAIS PÓS-SEPULTAMENTO}

No Brasil, no que se refere ao sepultamento das crianças, sabemos que elas eram comumente enterradas nas dependências das igrejas, tal como acontecia aos adultos. Nos viajantes, por volta das primeiras décadas do século XIX, começaram a aparecer referências a uma nova forma de enterramento nas igrejas: os carneiros. Estes consistiam em salas quadrangulares, em geral dando para um pátio aberto, tendo em suas paredes compartimentos de largura tal a poder caber um esquife ${ }^{76}$. Em relação ao antigo modo de enterrar, as catacumbas implicavam algumas novidades: além de eliminar o contato do corpo com a terra - sendo a decomposição favorecida pelo uso da cal que era despejada no defunto quando do fechamento do jazigo - e acentuar a separação entre vivos e mortos, conforme lembra João José Reis, torna regra 
a prática de sepultar-se o defunto junto com o caixão ${ }^{77}$. Já em 1817 Louis Freycinet atestou a existência desses espaços que, no entanto, de tão raros, ele havia tomado conhecimento de sua existência apenas por intermédio de M. Eshewege $^{78}$. Na Corte, já são três as igrejas que, ao fim da década de 1830, possuem esses recintos, segundo o que nos informa Debret: a da igreja do Carmo, a de São Francisco de Paula e a de Santo Antônio, visitadas por Ida Pfeifer, e mais tarde por Daniel Kidder ${ }^{79}$.

O que nos interessa nesse particular é o fato de existirem entre essas salas, algumas reservadas exclusivamente ao sepultamento de crianças. Com efeito, Debret fala de catacumbas com salas que contavam com compartimentos menores, reservadas para enterros de crianças, filhos dos irmãos ${ }^{80}$. No mesmo momento, por volta da década de 1820, o alemão Ernest Ebel confirma a existência desse espaço junto à Capela Real ${ }^{81}$. Ferdinand Denis em 1838, ao evocar uma desses recintos, também assinala a boa impressão que estes lhe deram. Segundo ele, é "de um asseio extremo e oferece elegante aspecto. As pinturas das arcadas são freqüentemente renovadas, e quase sempre este cemitério abrigado é contíguo a um pequeno jardim, onde crescem flores que se cultivam com cuidado, e que perfumam esta última morada da infância" ${ }^{\prime 2}$. Importa ressaltar que esses cemitérios verticais, na forma em que eram espacialmente organizados, mais do que reforçar a unidade da família nuclear, assinalavam a presença da comunidade dos irmãos. É desnecessário dizer que essa orientação estaria, já em meados do século XIX, que assiste a uma paulatina valorização dos sentimentos familiares, com seus dias contados.

Essa forma típica de disposição do cadáver, que era acompanhado do uso da cal, deu lugar precisamente num funeral de "anjo", a um conflito cultural de extremo interesse para nosso estudo. $O$ francês Victor-Athanase Gendrin nos conta sobre uma contenda séria que esse costume de enterrar fora da terra, fazendo uso da cal, gerou entre brasileiros e franceses no enterro da criança francesa da família Lefranc ${ }^{83}$. Num episódio ímpar, os franceses que participavam da cerimônia, indignados com o fato de que a criança não iria ser enterrada na terra, e talvez com a idéia de jogar cal em todo o seu corpo hábito que em outro viajante provocara repugnância, mesmo reconhecendo sua eficácia ${ }^{84}$ - esses senhores à força e ao fim de um imenso tumulto, conseguiram com sucesso retirar o cadáver das mãos dos responsáveis pelo serviço e, com instrumentos improvisados com o material que se encontrava no local, enterrar a criança no chão contíguo ao carneiro.

O luto está entre as outras práticas que têm lugar após os enterramentos, uma vez que ele se estende para os dias que se seguem ao evento. Esse costume diz respeito aos mecanismos que a sociedade possui para a manutenção da reprodução social, sempre quando a morte entra em cena. Ele ameniza a ruptura que a morte significa, substituindo por uma determinada conduta 
a presença real do falecido, permitindo aos poucos superá-la. Depende, portanto, da posição social que o morto tinha enquanto vivo. No período, a prática do luto entre os brasileiros foi também observada pelos estrangeiros. Em 1852, John Candler informava sobre costume no qual os parentes próximos do falecido ficavam em reclusão de luto durante oito dias. Esse mesmo autor acrescentaria, não obstante, que esse procedimento não se verifica para crianças menores de $10 \operatorname{anos}^{85}$. À criança, cujo papel social é de menor monta, não parece exigir com sua morte um esforço para o reordenamento da comunidade da qual faz parte.

O que não significava que, após a morte, a criança fosse completamente esquecida. Uma das ocasiões, após o enterro, em que a criança morta é lembrada pelos vivos, evento que ganhou maior popularidade com o advento dos carneiros, tem lugar no Dia de Todos os Santos (ou Dia de Finados). Nesse dia as famílias dos falecidos que foram sepultados nas catacumbas vinham visitar e muitas vezes receber os restos mortais de seus defuntos, como testemunhou o aventureiro inglês James Holman ${ }^{86}$. Esse costume era acompanhado por outro no qual as urnas das crianças, também ricamente adornadas, são expostas à visitação. Aqui se evidencia uma característica comum à morte das crianças das elites como um todo, que é de servir de instrumento de ostentação, possível pela liberalidade que a cerca. Segundo esses estrangeiros, no Dia de Todos os Santos as câmaras são ornadas com laços dourados e panos pretos, e as urnas decoradas com flores e tecidos, tendo em volta uma infinidade de castiçais e candelabros acesos. Estes lugares eram bastante freqüentados por jovens e velhos, durante o dia todo, com transeuntes indo de uma igreja a outra. Sobre o Rio de Janeiro, Debret nos fala da exposição anual dos sarcófagos nos dias de Finados e das visitas feitas às igrejas como as de Santo Antônio, São Francisco de Paula e do Carmo, segundo ele, "as mais elegantemente construídas", que, a partir de 1816 já contavam com uma multidão que corria a visitá-las. Sobre esses salões, ele observara o seguinte: urnas sobre estrados enfeitados de tules e galões de ouro aplicados em fileiras de três sobre veludo preto, carmesim, rosa ou azul-celeste, tudo rodeado por uma série de candelabros de prata, geralmente sob a vigilância de um negro, de libré $^{87}$. D. Kidder, já no final da década de 1830, fica bastante impressionado com estas exposições, o mesmo acontecendo a Ida Pfeifer vinte anos depois ${ }^{88}$.

É através de uma narrativa de viagem que temos a referência a instrumentos que favorecem a lembrança dos mortos, dos quais pode-se dizer que as crianças não estão excluídas: são as caixas de almas. As contribuições feitas às almas do purgatório por intermédio desta caixa, segundo o que notara Wetherell em 1860, não eram $\operatorname{raras}^{89}$. Thomas Ewbank (1945) descreve uma delas, em cuja ilustração do purgatório - ou, em todo caso, de algum lugar do além onde penas eram expiadas - estavam representadas nada menos que 
duas crianças, uma branca e outra negra, recurso que parecera ao autor extremamente eficiente para "figurar o tormento dos sofredores, e mostrar que todas as raças e idades estão expostas a eles"90. Como bem havia entendido Ewbank, essa caixa antes de mais nada deveria servir de receptáculo para as esmolas que seriam convertidas em ofícios dedicados a almas que estavam a padecer tormentos no além. Essa prática vem em reforço a uma determinada representação da morte já comum há cinco séculos no Ocidente católico, segundo a qual os vivos, por intermédio de missas e orações, podiam interceder positivamente em favor dos mortos que estavam a cumprir pena no purgatório.

No entanto, a despeito de reeditar uma concepção já tradicionalmente enraizada no imaginário fúnebre, essa caixa, particularmente, parece trazer uma novidade bastante importante. Conforme a descrição de Ewbank, ela representa crianças aguardando absolvição no fogo redentor daquele que é provavelmente o purgatório, uma vez que a ajuda dos vivos é de tão grande valia. O costume de recolher dinheiro segundo este pretexto mostra, de um lado, que a Igreja, por intermédio deste instrumento, assumia uma postura conflitante com a concepção de infância revelada pelo comportamento popular em relação à morte da criança. Ela anuncia uma concepção de morte que, diferentemente do que vimos da conduta leiga através das descrições, não separa a morte adulta daquela da criança. Como notara Ewbank, a Igreja estava a alertar que as penas do além chegam indistintamente segundo raça e idade. Em conseqüência dessa disposição, os representantes eclesiásticos entravam em franco desacordo com a crença popular na qual a criança tinha sua salvação garantida. Como já era exigido para os mortos adultos, essas autoridades, vislumbrando talvez o que isso poderia representar em termos de receita, passaram a criar temores, cautelas e cuidados onde antes (em termos ritualísticos, bem entendido) predominavam as certezas reconfortantes juntamente com as necessárias (quase obrigatórias) comemorações e homenagens.

Resta, ainda, o mais importante. A descrição da caixa confirma a hipótese com a qual buscamos ler os viajantes ao longo deste artigo, com o intuito de nos afastarmos dos preconceitos dos quais essas narrativas estavam embebidas. Como já foi dito, uma idéia bastante recorrente que os viajantes tiveram dos funerais de "anjinho" é que essas práticas seriam sintomas de um certo menoscabo em relação à criança, desprezo este que se revelaria pela ausência de elementos que expressassem o sofrimento que esse evento deveria dar lugar, tal como assim o entendiam esses estrangeiros. Vimos, não obstante, que os próprios relatos desses rituais constantemente nos informam de uma conduta que, ao contrário do que estes avaliaram, torna patente um apreço bastante significativo pela criança: ficou evidente, nas descrições dos múltiplos momentos em que se desdobra esse conjunto de gestos, um zelo intenso (como as das mães, livres e escravas, que depositam seus filhos mortos nas ro- 
das), muitas vezes assumido segundo um investimento exagerado em todos os detalhes de que nos restaram testemunhos, dos cuidados com a mortalha e os adereços que a acompanham até o asseio com que eram cuidados os espaços onde eram sepultadas. Além disso, os relatos nos dão a oportunidade de constatar que as ocasiões em que não pesava o rigor dos códigos ritualísticos (como os longos afagos que recebia o "anjo" visitado pelo francês Arago) tornavam propícias as demonstrações de inequívoco afeto para com a criança.

Ora, a expectativa do compadecimento das mães por parte da Igreja, que agia por meio da caixa, desfaz a crítica dos viajantes sobre o desdém dedicado às crianças entre os brasileiros. Ainda que a imagem que a caixa vinculava da morte infantil contrariasse frontalmente a concepção comum entre os brasileiros, ela evidenciava a disposição destes para com este assunto, uma vez que a Igreja entreviu nesse tema um canal eficaz para angariar dividendos. A eficiência da caixa dependia (e por isso é uma confirmação) da importância que a criança - em particular os problemas relacionados à sua morte - assumia junto à população da Corte, uma vez que mostra que a simples alusão a este assunto assegurava a compaixão e a justa contribuição daqueles que por ali passassem. À Igreja brasileira estava claro o que aos viajantes fora impossível atinar, a despeito, como vimos, das inúmeras oportunidades que lhes foram dadas: que as práticas e representações da morte infantil entre os brasileiros não eram resultado de um fraco apreço pela criança, mas ao contrário, tratava-se do fato de que essa determinada concepção de morte infantil tornava mais toleráveis os traumas e os pesares que a ocorrência de sua morte propiciava. Mais ainda, a conduta do episcopado brasileiro, fazendo uso da caixa, assinala que essa notável preocupação para com a criança a tal ponto estava presente nas atitudes que cercavam a sua morte, que somente por meio da mobilização desse desvelo é que seria possível uma mudança no imaginário fúnebre infantil no Brasil.

\section{NOTAS}

* Doutorando do programa em História Social da Universidade de São Paulo, sob orientação da Profa. Dra. Maria Helena Pereira Toledo Machado. A pesquisa tem contado com o apoio das bolsas de mestrado, e depois doutorado, concedidas pela CAPES e CNPq, respectivamente. Gostaria de agradecer pelas sugestões dos pareceristas.

${ }^{1} \mathrm{O}$ levantamento dos viajantes deveu imensamente à pesquisa realizada pelas historiadoras Mirian Lifchitz Moreira Leite, Maria Lúcia de Barros Mott de Melo Souza e Bertha Kauffmann Appenzeller, que foi publicada no livro A mulher no Rio de janeiro no século XIX. Um indice de referências em livros de viajantes estrangeiros. São Paulo: Fundação Carlos Chagas, 1982. 
${ }^{2}$ GÉLIS, Jacques. “A individualização da criança”. In DUBY, G. e ARIÈS, P. (orgs.) História da Vida Privada III. São Paulo: Companhia das Letras, 1986, p.315.

${ }^{3}$ ARIÈS, Philippe. História Social da Criança e da Família. Rio de Janeiro, Ed. Guanabara, 1973, p. 65.

${ }^{4}$ LAUWE, Chombart de. Um outro mundo: a infância. São Paulo: Perspectiva, EDUSP, 1991 , p. 9.

${ }^{5}$ VOVELLE, Michel. Ideologias e Mentalidades. São Paulo: Brasiliense, 1987.

${ }^{6}$ DEL PRIORE, Mary. “Apresentação” . In DEL PRIORE, Mary. História das Crianças no Brasil. São Paulo: Contexto, 1999, p. 11.

${ }^{7}$ KIDDER, Daniel Parish. Reminiscências de viagens e permanência nas províncias do Sul do Brasil: Rio de Janeiro e São Paulo: compreendendo notícias históricas e geográficas do Império e das diversas províncias (trad. Moacir N. Vasconcelos; notícia biográfica Rubens Borba de Morais) Belo Horizonte: Ed Itatiaia; São Paulo: Ed. da Universidade de São Paulo, 1980, p.159.

${ }^{8}$ KIDDER, Daniel Parish. Op. cit., p.158, e CANDLER, John and BURGESS. Narrative of a recent visit to Brazil. London: Edward Marsh, 1853.

${ }^{9}$ LUCCOCK, John. Notas sobre o Rio de Janeiro e partes meridionais do Brasil tomadas durante uma estada de dez anos nesse país de 1800 a 1818 (tradução de Milton da Silva Rodrigues). São Paulo: Livraria Martins, 1942, p.79.

${ }^{10}$ DENIS, Ferdinand. Brasil (trad. João Etienne Filho e Malta Lima). Belo Horizonte: Ed. Itatiaia; São Paulo: Ed. da Universidade de São Paulo, 1980, p.144.

${ }^{11}$ ARAGO, M. J. Souvenirs d'un Aveugle Voyage Autour du Monde. Tome Premier. Paris: Hortet et Ozanne, 1839, p.103.

${ }^{12}$ LUCCOCK, John. Op. cit., p.79.

${ }^{13}$ GRAHAM, Maria. Viagem ao Brasil. São Paulo: Companhia Editora Nacional, 1956; e KIDDER, Daniel Parish. Op. cit., p.158.

${ }^{14}$ DEBRET, Jean Baptiste. Viagem Pitoresca e Histórica ao Brasil. $2^{\text {a }}$ edição. Tomos I e II (volumes I, II e III), São Paulo: Livraria Martins Editora.

${ }^{15}$ ARAGO, M. J. Op. cit., p.102.

${ }^{16}$ KIDDER, Daniel Parish, Op. cit., p.158.

${ }^{17}$ STEWART, Charles Samuel. A visit to the South Seas in the U.S. Ship Vicennes, during the years 1829 and 1830; with notices of Brazil, Peru, Manulla, the Cape of Good Hope, and St. Helena. London: Fisher, Son, \& Jackson, 1832.

${ }^{18}$ DABADIE, F. A Travers L'Amérique du Sud. Paris: Ferdinand Sartorius, éditeur, 1858, p.7.

${ }^{19}$ FREYRE, Gilberto. Casa Grande \& Senzala. Rio de Janeiro: Record, 2000; e HOLANDA, Sérgio Buarque de. Raízes do Brasil. Rio de Janeiro: Editora José Olympio, 1971, pp.79 e 109.

${ }^{20}$ LUCCOCK, John. Op. cit., p.79; e KIDDER, Daniel Parish. Op. cit., p.158. 
${ }^{21}$ REIS, João José. A Morte é uma Festa: Ritos fúnebres e revolta popular no Brasil do século XIX. São Paulo: Cia das Letras, 1995; GUEDES, Sandra Pascoal Leite Camargo. Atitudes Perante a Morte em São Paulo (séculos XVII a XIX). Dissertação de Mestrado, São Paulo: Universidade de São Paulo, 1986. RODRIGUES, Cláudia. Lugares dos Mortos na Cidade dos Vivos. Dissertação de Mestrado, Niterói: Universidade federal Fluminense, 1995.

${ }^{22}$ Ver também EWBANK, Thomas. A vida no Brasil: ou, Diário de uma visita à terra do cacaueiro e das palmeiras, com um apêndice contendo ilustrações das artes sul-americanas antigas (trad. Jamil Almansur Haddad). Belo Horizonte: Ed. Itatiaia; São Paulo: Ed. da Universidade de São Paulo, 1976, p.45.

${ }^{23}$ RODRIGUES, Cláudia. Op. cit., pp.210-211.

${ }^{24}$ REIS, João José. Op. cit.

${ }^{25}$ DEBRET, Jean Baptiste. Op. cit., pp.29 e 37; EBEL, Ernst. Op. cit., p. 135; DENIS, Ferdinand. Op. cit., p.144; KIDDER, Daniel Parish. Op. cit., p.137; EWBANK, Thomas. Op. cit., pp.96 e 160; CANSTAT, OscaTr. Brasil. Terra e Gente (trad. Eduardo de Lima e Castro). Rio de Janeiro: Conquista, 1975, p. 208.

${ }^{26}$ SIEDLER, Carl, Dez anos no Brasil (tradução Bertholdo Klinger). Belo Horizonte: Ed. Itatiaia; São Paulo: Ed. da Universidade de São Paulo, 1980, p. 155; STEWART, Charles Samuel. Op. cit., p.158; CANDLER, John, and BURGESS. Op. cit., p.44.

${ }^{27}$ KIDDER, Daniel Parish. Op. cit., p.160; e DEBRET, Jean Baptiste. Op. cit.

${ }^{28}$ CHEVALIER, Jean e GHEERBRANT, Alain. Dicionário de Símbolos. RJ: José Olympio, 1995.

${ }^{29}$ PIKE, E. Royston. Diccionario de Religiones (Adaptación de Elsa Cecilia Frost) Fondo de Cultura Económica, 1960, p. 107 e ELIADE, Mircea (ed.). The Encyclopedia of Religion. New York: MacMillan Publishing Company, 1987, p.563.

${ }^{30} \mathrm{GENDRIN}$, Victor-Athanase. Récit historique, exact et sincère, par mer et par terre, de quattre voyages faits au Brèsil, au Chili, dans les Cordillères de Andes, à Mendoza, dans le Désert, et à Buenos-Aires. Versalhes: Gendrin, 1856, p.63.

${ }^{31}$ ARAGO, M. J. Op. cit., p.102.

${ }^{32}$ EBEL, Ernst, Op. cit., p. 135; DENIS, Ferdinand. Op. cit., p.148; KIDDER, Daniel P. Op. cit., p.158; SIEDLER, Carl. Op. cit., p.156; WETHERELL, James. Brazil. Stray Notes from Bahia Being Extracts from Letters, \& C., During a Residence of Fifteen Years. Liverpool: Webb and Hunt, 1860, p.111.

${ }^{33}$ WETHERELL, James. Op. cit., p.111.

${ }^{34}$ CHEVALIER, Jean e GHEERBRANT. Op. cit., p.289.

${ }^{35}$ KIDDER, Daniel Parish. Op. cit., p.160; DENIS, Ferdinand. Op. cit., p.148; DEBRET, Jean Baptiste, Op. cit., p.211.

${ }^{36}$ DEBRET, Jean Baptiste. Op. cit., p.211.

${ }^{37}$ EBEL, Ernst. Op. cit., p. 135.

${ }^{38}$ EWBANK, Thomas. Op. cit., p.58; e DICKINS, Marguerite. Along shore with a man-ofwar. Boston: Arena Publishing Company, 1893, p.23. 
${ }^{39}$ ELIADE, Mircea. Op. cit., p. 563.

${ }^{40}$ LINDEY, Thomas. Narrative of a Voyage to Brazil. London: Printed for J. Johnson. St Paul's Church-Yard: 1805, p.65.

${ }^{41}$ GENDRIN, Victor-Athanase. Op. cit., p.63.

${ }^{42}$ KIDDER, Daniel Parish. Op. cit., p.160.

${ }^{43}$ DEBRET, Jean Baptiste. Op. cit., p.219.

${ }^{44}$ GENDRIN, Victor-Athanase. Op. cit., p.63.

${ }^{45}$ KIDDER, Daniel Parish. Op. cit., p.160.

${ }^{46}$ QUEIRÓS, Suely Robles Reis de. São Paulo. Madrid: Ed. Mapfre, 1992, p.126 e QUEIROZ, Maria Isaura Pereira de. Cultura, sociedade rural, sociedade urbana no Brasil. Rio de Janeiro: Livros Técnicos e Científicos; São Paulo: Edusp, 1978, p.73.

${ }^{47}$ KIDDER, Daniel Parish. Op. cit., p.160.

${ }^{48}$ ARAGO, M. J. Op. cit., p.102.

${ }^{49}$ STEWART, Charles Samuel. Op. cit., p.49.

${ }^{50}$ EWBANK, Thomas. Op. cit., p.59.

${ }^{51}$ LUCCOCK, John. Op. cit., p.79.

${ }^{52}$ EBEL, Ernst. Op. cit., p. 135.

${ }^{53}$ WETHERELL, James. Op. cit., p.111.

${ }^{54}$ ANDREWS, Christopher Columbus. Brazil - Its condition and prospects. New York: C. Appleton and Company, 1887, p.56; CANDLER, John, and BURGESS. Op. cit., p.45.

${ }^{55}$ LUCCOCK, John. Op. cit., p.79, e EBEL, Ernst. Op. cit., p.135.

${ }^{56}$ ARAGO, M. J. Op. cit., p.102.

${ }^{57}$ Idem.

${ }^{58}$ SIEDLER, Carl. Op. cit., p.156.

${ }^{59}$ KIDDER, Daniel Parish. Op. cit., p. 158.

${ }^{60}$ MINTURN JR., Robert B. From New York to Delhi by way of Rio de Janeiro, Australia and China. New York: D. Appleton \& Co. 1858, p. 15.

${ }^{61}$ WETHERELL, James. Op. cit., p.111.

${ }^{62}$ DICKINS, Marguerite. Along shore with a man-of-war. Boston: Arena Publishing Company, 1893, p.21.

${ }^{63}$ DEBRET, Jean Baptiste. Op. cit., p. 182, e KIDDER, Daniel Parish. Op. cit., pp.160-1.

${ }^{64}$ DOUVILLE, J. B. 30 mois de ma vie, ou Quinze mois avant et quinze mois après mon Voyage au Congo, accompagné de pièces justificatives, détails nouveaux et curieux sur les moeurs et les usages des habitans du Brésil et de Buenos-Ayres, et d'une description de la colonie patagonia. Paris: Dentu et Delaunay Librarie, 1833, p.235.

${ }^{65}$ GENDRIN, Victor-Athanase. Op. cit., p. 63. 
${ }^{66}$ KIDDER, Daniel Parish. Op. cit., p. 158.

${ }^{67}$ CANDLER, John, and BURGESS. Op. cit., p. 44.

${ }^{68}$ CANSTAT, Oscar. Op. cit., p.191.

${ }^{69}$ ANDREWS, Christopher Columbus. Op. cit., p.56.

${ }^{70}$ MINTURN JR., Robert B. Op. cit., p.15.

${ }^{71}$ WETHERELL, James. Op. cit., p.111.

${ }^{72}$ MINTURN JR., Robert B. From New York to Delhi by way of Rio de Janeiro, Australia and China. New York: D. Appleton \& Co. 1858, p. 15.

${ }^{73}$ DICKINS, Marguerite. Op. cit., p.21.

${ }^{74}$ MAC-ÉRIN, U. Huit mois sur les deux Océans. Voyage d' études et d'agrément. Paris: Cattier.

${ }^{75}$ DICKINS, Marguerite. Op. cit., p. 58.

${ }^{76} \mathrm{HOLMAN}$, James. A voyage round the world, including travels in Africa, Asia, Australia, America, etc. etc., from 1827 to 1832. Vol. 1, London: Smith, Elter, and Co., 1834, p.61.

${ }^{77}$ REIS, João José. "O Cotidiano da Morte no Brasil Oitocentista." In ALENCASTRO, Luiz Felipe de (org.). História da Vida Privada no Brasil. 2. São Paulo: Companhia das Letras, 1997, p.95.

${ }^{78}$ FREYCINET, Louis de. Voyage autour du Monde fait par ordre du Roi. Paris: Pillêt Aîné, 1825, p.209.

${ }^{79}$ Ver: DEBRET, Jean Baptiste. Op. cit., pp.218-9; PFEIFER, Ida. A Woman's Journey Round The World. From Vienna to Brazil, Chili, Tahiti, China, Hindostan, Persia, and Asia Minor. London: Nathaniel Cookie, 1854, p.12, e KIDDER, Daniel Parish. Op. cit., p.158.

${ }^{80}$ DEBRET, Jean Baptiste. Op. cit., p.219.

${ }^{81}$ EBEL, Ernst. Op. cit., p. 135.

${ }^{82}$ DENIS, Ferdinand. Op. cit., p.148.

${ }^{83}$ GENDRIN, Victor-Athanase. Op. cit., p.63.

${ }^{84}$ EBEL, Ernst. Op. cit., p. 135.

${ }^{85}$ CANDLER, John, and BURGESS. Op. cit., p.44.

${ }^{86}$ HOLMAN, James. Op. cit., pp. 61-63.

${ }^{87}$ DEBRET, Jean Baptiste. Op. cit., pp.219-220.

${ }^{88}$ PFEIFER, Ida. Op. cit., p.22 e KIDDER, Daniel Parish. Op. cit., p.162.

${ }^{89}$ WETHERELL, James. Op. cit., p.112.

${ }^{90}$ EWBANK, Thomas. Op. cit., p.215.

Artigo recebido em 06/2002. Aprovado em 09/2002. 